\title{
Group-Contribution Estimation of the Critical Properties of Hydrocarbons
}

\author{
N. Skander ${ }^{1}$ and C.E. Chitour ${ }^{2}$ \\ 1 Centre de Recherche et Développement de Sonatrach, Boumerdès - Algérie \\ 2 Laboratoire de Valorisation des Energies Fossiles, Département de Génie Chimique, École Nationale Polytechnique, Alger - Algérie \\ sankernachida@yahoo.fr - Vdida2003@yahoo.fr
}

Résumé - Estimation des propriétés critiques des hydrocarbures par contribution de groupe Une méthode de contribution de groupe a été développée pour prédire les températures, pressions et volumes critiques des composés hydrocarbonés. La méthode a été établie avec une assez bonne précision, les déviations absolues moyennes enregistrées entre les valeurs expérimentales et celles calculées sont de $0.36 \%, 4.6 \%$ et $1.7 \%$ respectivement pour la température critique, la pression critique et le volume critique.

\begin{abstract}
Group-Contribution Estimation of the Critical Properties of Hydrocarbons - A groupcontribution method was developed to predict critical tempertaures, pressures and volumes of hydrocarbon compounds. The method was tested with satisfactory accuracy. The absolute average deviations obtained between experimental and calculated values are $0.36 \%, 4.6 \%$ and $1.7 \%$ respectively for critical temperature, critical pressure and critical volume.
\end{abstract}




\section{NOTATIONS}

$\begin{array}{ll}\text { AAD } & \text { average absolute deviation } \\ a, b, c, d, m, n, p & \text { constants for each property in Equation } \mathrm{F} \\ T_{C} & \text { critical temperature }(\mathrm{K}) \\ P_{C} & \text { critical pressure }(\mathrm{bar}) \\ V_{C} & \text { critical volume }\left(\mathrm{cm}^{3} / \mathrm{mol}\right) \\ F & \text { mathematical function } \\ M & \text { molecular weight }(\mathrm{g} / \mathrm{mol}) \\ T_{b} & \text { normal boiling point }(\mathrm{K})\end{array}$

\section{Greek symbols}

$\theta \quad$ a given property

$\Delta \theta_{i}$ contribution of the group $i$ for the estimation of the property $\theta$

\section{INTRODUCTION}

The knowledge of the critical properties of pure compounds is primordial when using corresponding state correlations and in equation of state calculations.

Experimental determination of these properties proved to be difficult and subject to high uncertainty due essentially to the thermal decomposition of these compounds.

Many methods estimating these parameters have been proposed in literature, and the group- contribution approach was generally used. In this technique, it is assumed that some property is a function of the molecule structure, e.g. the number and types of chosen molecular structures each of which is assigned a numerical value.

Examples of such methods include those of Lydersen (1955), Joback and Reid (1984), Ambrose (1980) and Klincewicz and Reid (1984). Even if these correlations are able to estimate the properties quite rapidly, many of them fail in distinguishing among isomers due to the oversimplification of the molecule structure or, in extrapolating to long chain paraffins. More recently, Constantinou and Gani (1994, 1995) and Marrero and Gani (2001) improved the methods by introducing in their methods new groups which allow to describe the various molecular structures and their isomers. In the same context, our study aims to develop new groupcontribution correlations to estimate critical temperatures $T_{C}$ $(\mathrm{K})$, critical pressures $P_{C}$ (bar) and critical volumes $V_{C}$ $\left(\mathrm{cm}^{3} / \mathrm{mol}\right)$ of pure hydrocarbons. The proposed correlations are able to fit the data with relatively small errors.

\section{PROPOSED METHOD}

This study was carried out on the basis of a data base containing 357 hydrocarbons for which experimental crit- ical properties are available. Most of these data were obtained from the compilation of TRC data bank (TRC, Thermodynamic Data Base, version 1.3, 1994). Some additional data (above $\mathrm{C}_{20}$ ) were obtained from the DIPPR Data compilation of pure compound properties (1985).

The first step consists in selecting the atomic groups to be used. We benefited greatly from the experience of previous workers. We generated 10 types of structural groups: $\mathrm{CH}_{3}$, $\mathrm{CH}_{2}, \mathrm{CH}, \mathrm{C},=\mathrm{CH}_{2},=\mathrm{CH},=\mathrm{C},=\mathrm{C}=$, $\equiv \mathrm{CH}$ and $\equiv \mathrm{C}$, and considered at first approximation that any carbon atom appearing in a ring structure is considered equivalent to nonring carbon. In a second step, we included correction terms to take into account some specific structures. Thus, terms were affected to allow proximity effects of $\mathrm{CH}_{3}$ groups in hydrocarbons which belong to the isoparaffin family. Terms were assigned to ring correction to correct for possible stress- strain effects in such molecules. Cis and trans contribution groups are also included to take care of isomerization in naphthene and alkene compounds. For aromatic structures, a ring correction was added in addition to those relative to ortho, meta and para substitutions and other substitution types.

A total of 40 groups were generated.

\section{TABLE 1}

The different forms of Equation 1

\begin{tabular}{|c|c|}
\hline Equation 1.1 & $\theta=b . \Sigma \Delta \theta_{I}$ \\
\hline Equation 1.2 & $\operatorname{Exp}(\theta / p)=b . \Sigma \Delta \theta_{\mathrm{i}}$ \\
\hline Equation 1.3 & $(1 / \theta)^{p}=b . \Sigma \Delta \theta_{\mathrm{i}}$ \\
\hline Equation 1.4 & $(\mathrm{M} / \theta)=b . \Sigma \Delta \theta_{\mathrm{i}}$ \\
\hline Equation 1.5 & $(\mathrm{~Tb} / \theta)=b \cdot \Sigma \Delta \theta_{\mathrm{i}}$ \\
\hline Equation 1.6 & $\theta=a+b \cdot \Sigma \Delta \theta_{\mathrm{i}}$ \\
\hline Equation 1.7 & $\operatorname{Exp}(\theta / p)=a+b \cdot \Sigma \Delta \theta_{\mathrm{i}}$ \\
\hline Equation 1.8 & $(1 / \theta)^{p}=a+b \cdot \Sigma \Delta \theta_{\mathrm{i}}$ \\
\hline Equation 1.9 & $(\mathrm{M} / \theta)=a+b \cdot \Sigma \Delta \theta_{\mathrm{i}}$ \\
\hline Equation 1.10 & $(\mathrm{~Tb} / \theta)=a+b . \Sigma \Delta \theta_{\mathrm{i}}$ \\
\hline Equation 1.11 & $\theta=a+b . \Sigma \Delta \theta_{\mathrm{i}}+c .\left(\Sigma \Delta \theta_{\mathrm{i}}\right)^{m}$ \\
\hline Equation 1.12 & $\operatorname{Exp}(\theta / p)=a+b \cdot \Sigma \Delta \theta_{\mathrm{i}}+c \cdot\left(\Sigma \Delta \theta_{\mathrm{i}}\right)^{m}$ \\
\hline Equation 1.13 & $(1 / \theta)^{p}=a+b \cdot \Sigma \Delta \theta_{\mathrm{i}}+c \cdot\left(\Sigma \Delta \theta_{\mathrm{i}}\right)^{m}$ \\
\hline Equation 1.14 & $(\mathrm{M} / \theta)=a+b \cdot \Sigma \Delta \theta_{\mathrm{i}}+c \cdot\left(\Sigma \Delta \theta_{\mathrm{i}}\right)^{m}$ \\
\hline Equation 1.15 & $(\mathrm{~Tb} / \theta)=a+b \cdot \Sigma \Delta \theta_{\mathrm{i}}+c \cdot\left(\Sigma \Delta \theta_{\mathrm{i}}\right)^{m}$ \\
\hline Equation 1.16 & $\theta=a+b \cdot \Sigma \Delta \theta_{\mathrm{i}}+c \cdot\left(\Sigma \Delta \theta_{\mathrm{i}}\right)^{m}+d .\left(\Sigma \Delta \theta_{\mathrm{i}}\right)^{n}$ \\
\hline Equation 1.17 & $\operatorname{Exp}(\theta / p)=a+b \cdot \Sigma \Delta \theta_{\mathrm{i}}+c \cdot\left(\Sigma \Delta \theta_{\mathrm{i}}\right)^{m}+d \cdot\left(\Sigma \Delta \theta_{\mathrm{i}}\right)^{n}$ \\
\hline Equation 1.18 & $(1 / \theta)^{p}=a+b \cdot \Sigma \Delta \theta_{\mathrm{i}}+c \cdot\left(\Sigma \Delta \theta_{\mathrm{i}}\right)^{m}+d \cdot\left(\Sigma \Delta \theta_{\mathrm{i}}\right)^{n}$ \\
\hline Equation 1.19 & $(\mathrm{M} / \theta)=a+b \cdot \Sigma \Delta \theta_{\mathrm{i}}+c \cdot\left(\Sigma \Delta \theta_{\mathrm{i}}\right)^{m}+d \cdot\left(\Sigma \Delta \theta_{\mathrm{i}}\right)^{n}$ \\
\hline Equation 1.20 & $(\mathrm{~Tb} / \theta)=a+b \cdot \Sigma \Delta \theta_{\mathrm{i}}+c \cdot\left(\Sigma \Delta \theta_{\mathrm{i}}\right)^{m}+d \cdot\left(\Sigma \Delta \theta_{\mathrm{i}}\right)^{n}$ \\
\hline
\end{tabular}


TABLE 2

Comparison between the $\mathrm{AAD}(\%)$ of the different equations predicting critical temperature

\begin{tabular}{|c|c|c|c|c|c|c|c|}
\hline & n-paraffins & i-paraffins & Alkenes & alkynes & naphthenes & aromatics & $\operatorname{AAD}(\%)$ \\
\hline Data Points & 25 & 139 & 52 & 22 & 52 & 65 & 355 \\
\hline Carbon range & $\mathrm{C}_{2}-\mathrm{C}_{40}$ & $\mathrm{C}_{4}-\mathrm{C}_{10}$ & $\mathrm{C}_{2}-\mathrm{C}_{20}$ & $\mathrm{C}_{2}-\mathrm{C}_{20}$ & $\mathrm{C}_{3}-\mathrm{C}_{22}$ & $\mathrm{C}_{6}-\mathrm{C}_{28}$ & \\
\hline Equation 1.2 & 0.9 & 1.1 & 1.0 & 1.0 & 1.6 & 1.4 & 1.2 \\
\hline Equation 1.5 & 2.3 & 0.7 & 2.2 & 3.3 & 1.7 & 1.3 & 1.4 \\
\hline Equation 1.7 & 0.9 & 1.1 & 1.0 & 1.0 & 1.6 & 1.4 & 1.2 \\
\hline Equation 1.10 & 2.3 & 0.7 & 2.2 & 3.3 & 1.7 & 1.3 & 1.4 \\
\hline Equation 1.11 & 0.2 & 1.0 & 0.7 & 1.3 & 1.0 & 1.2 & 1.0 \\
\hline Equation 1.12 & 0.5 & 1.0 & 1.0 & 1.2 & 1.3 & 1.3 & 1.1 \\
\hline Equation 1.13 & 0.2 & 1.0 & 2.1 & 1.4 & 1.0 & 1.1 & 1.1 \\
\hline Equation 1.14 & 0.2 & 0.9 & 0.9 & 1.9 & 0.8 & 1.2 & 1.0 \\
\hline Equation 1.15 & 0.2 & 0.3 & 0.3 & 0.8 & 0.4 & 0.4 & 0.4 \\
\hline Equation 1.16 & 0.1 & 1.0 & 0.7 & 1.2 & 1.0 & 1.1 & 0.9 \\
\hline Equation 1.17 & 0.3 & 1.0 & 0.7 & 1.3 & 1.2 & 1.3 & 1.0 \\
\hline Equation 1.18 & 0.2 & 1.0 & 0.7 & 1.2 & 1.0 & 1.1 & 0.9 \\
\hline Equation 1.19 & 0.2 & 0.9 & 0.8 & 1.9 & 0.8 & 1.2 & 1.0 \\
\hline Equation 1.20 & 0.1 & 0.3 & 0.3 & 0.8 & 0.4 & 0.4 & 0.4 \\
\hline
\end{tabular}

TABLE 3

Comparison between the $\mathrm{AAD}(\%)$ of the different equations predicting critical pressure

\begin{tabular}{|c|c|c|c|c|c|c|c|}
\hline & n-paraffins & i-paraffins & Alkenes & alkynes & naphthenes & aromatics & $\operatorname{AAD}(\%)$ \\
\hline Data Points & 26 & 139 & 53 & 22 & 52 & 65 & 357 \\
\hline Carbon range & $\mathrm{C}_{2}-\mathrm{C}_{40}$ & $\mathrm{C}_{4}-\mathrm{C}_{10}$ & $\mathrm{C}_{2}-\mathrm{C}_{20}$ & $\mathrm{C}_{2}-\mathrm{C}_{20}$ & $\mathrm{C}_{3}-\mathrm{C}_{22}$ & $\mathrm{C}_{6}-\mathrm{C}_{28}$ & \\
\hline Equation 1.8 & 4.9 & 0.5 & 2.6 & 5.0 & 7.9 & 5.7 & 3.4 \\
\hline Equation 1.11 & 4.8 & 0.5 & 3.5 & 4.8 & 10.5 & 6.5 & 4.1 \\
\hline Equation 1.12 & 6.3 & 0.5 & 3.5 & 6.5 & 9.4 & 7.0 & 4.2 \\
\hline Equation 1.13 & 7.3 & 0.5 & 3.8 & 7.2 & 11.3 & 6.5 & 4.6 \\
\hline Equation 1.14 & 4.1 & 0.6 & 2.3 & 4.1 & 6.5 & 5.2 & 3.0 \\
\hline Equation 1.15 & 4.3 & 0.5 & 2.5 & 5.1 & 6.9 & 5.4 & 3.2 \\
\hline Equation 1.16 & 6.6 & 0.5 & 3.6 & 4.3 & 8.2 & 6.8 & 3.9 \\
\hline Equation 1.17 & 6.0 & 0.5 & 3.1 & 3.8 & 7.6 & 6.5 & 3.6 \\
\hline Equation 1.18 & 2.4 & 0.6 & 2.0 & 5.5 & 6.3 & 5.2 & 2.9 \\
\hline Equation 1.19 & 4.1 & 0.6 & 2.4 & 4.2 & 6.6 & 5.1 & 3.0 \\
\hline Equation 1.20 & 4.3 & 0.5 & 2.5 & 5.1 & 6.9 & 5.4 & 3.2 \\
\hline
\end{tabular}

The next step in developing the group- contribution model involves the determination of the group increments. To obtain these values, the Levenberg-Marquardt method for non linear- least- square regression was used. This algorithm minimises the sum of squares of the difference between the true values and the predicted ones.
A generalised group- contribution equation in the form shown below was used to develop the model:

$$
\mathrm{F}(\theta)=a+b \Sigma \Delta \theta_{\mathrm{i}}+c\left(\Sigma \Delta \theta_{\mathrm{i}}\right)^{m}+d\left(\Sigma \Delta \theta_{\mathrm{i}}\right)^{n}
$$

where $\theta$ is a given property and $\mathrm{F}(\theta)$ a mathematical function 
TABLE 4

Comparison between the $\mathrm{AAD}(\%)$ of the different equations predicting critical volume

\begin{tabular}{|c|c|c|c|c|c|c|c|}
\hline & n-paraffins & i-paraffins & Alkenes & alkynes & naphthenes & aromatics & $\mathbf{A A D}(\%)$ \\
\hline Data Points & 24 & 139 & 53 & 22 & 51 & 65 & 354 \\
\hline Carbon range & $\mathrm{C}_{2}-\mathrm{C}_{36}$ & $\mathrm{C}_{4}-\mathrm{C}_{10}$ & $\mathrm{C}_{2}-\mathrm{C}_{20}$ & $\mathrm{C}_{2}-\mathrm{C}_{20}$ & $\mathrm{C}_{3}-\mathrm{C}_{22}$ & $\mathrm{C}_{6}-\mathrm{C}_{28}$ & \\
\hline Equation 1.1 & 1.6 & 0.9 & 1.7 & 2.6 & 1.8 & 3.0 & 1.7 \\
\hline Equation 1.3 & 1.7 & 0.9 & 1.1 & 1.0 & 1.5 & 3.1 & 1.5 \\
\hline Equation 1.6 & 1.7 & 0.9 & 1.8 & 2.8 & 1.8 & 3.0 & 1.7 \\
\hline Equation 1.7 & 1.9 & 0.9 & 1.8 & 3.0 & 1.8 & 3.0 & 1.8 \\
\hline Equation 1.8 & 1.5 & 0.9 & 1.1 & 0.8 & 1.6 & 3.0 & 1.4 \\
\hline Equation 1.9 & 3.1 & 1.0 & 2.0 & 1.2 & 1.3 & 4.4 & 1.9 \\
\hline Equation 1.11 & 1.5 & 0.9 & 1.1 & 0.8 & 1.6 & 3.0 & 1.4 \\
\hline Equation 1.12 & 1.5 & 0.8 & 1.5 & 1.8 & 0.7 & 3.2 & 1.4 \\
\hline Equation 1.13 & 1.4 & 0.8 & 1.2 & 1.3 & 1.0 & 3.1 & 1.4 \\
\hline Equation 1.14 & 3.1 & 1.0 & 2.0 & 1.2 & 1.3 & 4.3 & 1.9 \\
\hline Equation 1.15 & 1.4 & 1.3 & 1.1 & 3.8 & 1.8 & 4.7 & 2.1 \\
\hline Equation 1.16 & 1.5 & 0.9 & 1.1 & 0.9 & 1.6 & 3.0 & 1.4 \\
\hline Equation 1.17 & 0.8 & 1.0 & 1.7 & 1.4 & 1.4 & 3.4 & 1.6 \\
\hline Equation 1.18 & 1.4 & 0.8 & 1.2 & 1.3 & 1.0 & 3.1 & 1.4 \\
\hline Equation 1.19 & 3.1 & 1.0 & 1.9 & 1.2 & 1.3 & 4.4 & 2.0 \\
\hline Equation 1.20 & 1.4 & 1.3 & 1.0 & 3.7 & 1.8 & 4.7 & 2.1 \\
\hline
\end{tabular}

equal to $\theta, \exp (\theta / p), 1 / \theta^{p}, M / \theta$ or $T_{b} / \theta$. The parameters $a, b$, $c, d, m, n$ and $p$ are constants determined by the regression. $T_{b}(\mathrm{~K})$ and $M(\mathrm{~g} / \mathrm{mol})$ are respectively the boiling point and the molecular weight.

Twenty equations can be derived from Equation (1) according to the shape of the function $\mathrm{F}$ and by cancelling one or several parameters in the expression of the generalised correlation, as shown in Table 1. The aim of this approach is to test different forms of mathematical equations to provide the best correlation with minimum error.

In order to test the reliability of the different equations, the average absolute deviations AAD (\%) registered in the case of each hydrocarbon family are determined for each one.

\section{RESULTS AND DISCUSSION}

The results obtained are summarised in Tables 2, 3 and 4, respectively for critical temperature, critical pressure and critical volume. The number of data used for each regression, and their distribution in terms of carbon atom numbers are also given in these tables.

When selecting the equation that best fitted the data, we compared between the deviations registered by the different equations tested taking into account all the families. Also, we compared their ability in extrapolating the data to long chain paraffins.

The selection of the best equations for estimating critical temperatures is made by using the normal boiling point and the groups present in the molecule as parameters. The model selected has registered an average absolute deviation of $0.36 \%$ and has the following form:

\section{Equation 1.15:}

$$
\left(T_{b} / T_{C}\right)=a+b \cdot \Sigma \Delta T_{C i}+c\left(\Sigma \Delta T_{C i}\right)^{m}
$$

For critical pressure, only the group increments are needed and the model selected has the following form:

Equation 1.13:

$$
\left(1 / P_{C}\right)^{p}=a+b \Sigma \Delta P_{C i}+c\left(\Sigma \Delta P_{C i}\right)^{m}
$$

The absolute average deviation obtained by comparing the model to experimental data is equal to $4.6 \%$.

The model selected for estimating the critical volume is:

\section{Equation 1.1:}

$$
V_{C}=b . \Sigma \Delta V_{C i}
$$


TABLE 5

Equation parameters and group increment values

\begin{tabular}{|c|c|c|c|}
\hline & \\
\hline & $T_{c}$ & $\boldsymbol{P}_{c}$ & $V_{c}$ \\
\hline \multicolumn{4}{|c|}{ Parameter values } \\
\hline$p$ & - & $3.76621 \mathrm{E}-01$ & - \\
\hline$a$ & $3.75032 \mathrm{E}-02$ & $2.32562 \mathrm{E}-01$ & - \\
\hline$b$ & $-3.52119 \mathrm{E}-03$ & $3.05702 \mathrm{E}-02$ & $5.32007 \mathrm{E}+00$ \\
\hline$c$ & 6.74016E-01 & $6.20589 \mathrm{E}-02$ & - \\
\hline$d$ & - & - & - \\
\hline$m$ & $1.91890 \mathrm{E}-01$ & 8.29137E-01 & - \\
\hline$n$ & - & - & - \\
\hline \multicolumn{4}{|c|}{ Contributions } \\
\hline$-\mathrm{CH}_{3}$ & $1.99670 \mathrm{E}-01$ & $1.98848 \mathrm{E}-05$ & $1.31664 \mathrm{E}+01$ \\
\hline$-\mathrm{CH}_{2^{-}}$ & $9.15532 \mathrm{E}-02$ & $1.12008 \mathrm{E}-01$ & $1.06879 \mathrm{E}+01$ \\
\hline$-\mathrm{CH}<$ & $-6.11156 \mathrm{E}-02$ & $2.01649 \mathrm{E}-01$ & $5.15453 \mathrm{E}+00$ \\
\hline$>\mathrm{C}<$ & $-2.48688 \mathrm{E}-01$ & $2.45728 \mathrm{E}-01$ & $-9.39285 \mathrm{E}-01$ \\
\hline$=\mathrm{CH}_{2}$ & $1.89248 \mathrm{E}-01$ & $1.11136 \mathrm{E}-02$ & $1.18505 \mathrm{E}+01$ \\
\hline$=\mathrm{CH}-$ & $7.10096 \mathrm{E}-02$ & $5.37104 \mathrm{E}-02$ & $8.20223 \mathrm{E}+00$ \\
\hline$=\mathrm{C}<$ & \begin{tabular}{|l|}
$-5.34718 \mathrm{E}-02$ \\
\end{tabular} & $1.15424 \mathrm{E}-01$ & 4.70117E+00 \\
\hline$=\mathrm{C}=$ & $4.92851 \mathrm{E}-02$ & $-2.22262 \mathrm{E}-02$ & $9.52029 \mathrm{E}+00$ \\
\hline$=-\mathrm{CH}$ & $2.02609 \mathrm{E}-01$ & $3.96981 \mathrm{E}-07$ & $9.02010 \mathrm{E}+00$ \\
\hline$=-\mathrm{C}-$ & $6.07703 \mathrm{E}-02$ & $3.42040 \mathrm{E}-02$ & $6.68835 \mathrm{E}+00$ \\
\hline
\end{tabular}

Corrections terms owed to the $\mathrm{CH}_{3}$ proximity effects

\begin{tabular}{l|c|c|c}
\hline $\mathrm{C}\left(\mathrm{CH}_{3}\right)_{3}$ & $3.53048 \mathrm{E}-02$ & $3.73376 \mathrm{E}-02$ & $4.22093 \mathrm{E}+00$ \\
\hline $\mathrm{C}\left(\mathrm{CH}_{3}\right)_{2}$ & $7.25627 \mathrm{E}-03$ & $8.81017 \mathrm{E}-03$ & $1.82988 \mathrm{E}+00$ \\
\hline $\mathrm{C}\left(\mathrm{CH}_{3}\right)$ & $-6.78177 \mathrm{E}-03$ & $-1.62746 \mathrm{E}-02$ & $-1.02605 \mathrm{E}-01$ \\
\hline $\mathrm{C}\left(\mathrm{CH}_{3}\right) \mathrm{C}\left(\mathrm{CH}_{3}\right)$ & $1.72578 \mathrm{E}-03$ & $6.44537 \mathrm{E}-04$ & $5.58189 \mathrm{E}-01$ \\
\hline $\mathrm{C}\left(\mathrm{CH}_{3}\right) \mathrm{C}\left(\mathrm{CH}_{3}\right)_{2}$ & $6.58727 \mathrm{E}-03$ & $-9.25088 \mathrm{E}-03$ & $3.74734 \mathrm{E}-01$ \\
\hline $\mathrm{C}\left(\mathrm{CH}_{3}\right)^{2}\left(\mathrm{CH}_{3}\right)_{3}$ & $-1.37746 \mathrm{E}-02$ & $-1.15443 \mathrm{E}-02$ & $-4.72746 \mathrm{E}-01$ \\
\hline $\mathrm{C}\left(\mathrm{CH}_{3}\right)_{2} \mathrm{C}\left(\mathrm{CH}_{3}\right)_{2}$ & $-1.13700 \mathrm{E}-02$ & $-4.75291 \mathrm{E}-02$ & $-6.13219 \mathrm{E}-01$ \\
\hline $\mathrm{C}\left(\mathrm{CH}_{3}\right)_{2} \mathrm{C}\left(\mathrm{CH}_{3}\right)_{3}$ & $-2.57257 \mathrm{E}-02$ & $-5.68499 \mathrm{E}-02$ & $-1.08514 \mathrm{E}+00$ \\
\hline
\end{tabular}

Corrections terms owed to the types of positions

\begin{tabular}{l|l|l|l|l}
\hline cis & $7.68223 \mathrm{E}-03$ & $2.14235 \mathrm{E}-02$ & $1.54374 \mathrm{E}+00$ \\
\hline trans & $2.00218 \mathrm{E}-02$ & $5.62534 \mathrm{E}-02$ & $1.67532 \mathrm{E}+00$ \\
\hline \multicolumn{4}{|c}{ Corrections terms owed to the ring structure } \\
\hline 3 membered ring & $1.33081 \mathrm{E}-01$ & $-3.36020 \mathrm{E}-01$ & $-1.46258 \mathrm{E}+00$ \\
\hline 4 membered ring & $1.12379 \mathrm{E}-01$ & $-3.63950 \mathrm{E}-01$ & $-3.09044 \mathrm{E}+00$ \\
\hline 5 membered ring & $1.12121 \mathrm{E}-01$ & $-2.91276 \mathrm{E}-01$ & $-3.10119 \mathrm{E}+00$ \\
\hline 6 membered ring & $7.88993 \mathrm{E}-02$ & $-3.04600 \mathrm{E}-01$ & $-4.96039 \mathrm{E}+00$ \\
\hline 7 membered ring & $-2.96855 \mathrm{E}-02$ & $-4.40665 \mathrm{E}-01$ & $-7.33493 \mathrm{E}+00$ \\
\hline 8 membered ring & $-8.32130 \mathrm{E}-02$ & $-4.69314 \mathrm{E}-01$ & $-8.81242 \mathrm{E}+00$ \\
\hline 9 membered ring & $-1.38309 \mathrm{E}-01$ & $-4.88434 \mathrm{E}-01$ & $-1.02899 \mathrm{E}+01$ \\
\hline 10 membered ring & $-1.82415 \mathrm{E}-01$ & $-4.85558 \mathrm{E}-01$ & $-1.17674 \mathrm{E}+01$ \\
\hline \multicolumn{1}{|c|}{ Corrections terms owed to the aromatic structure } \\
\hline Aromatic ring & $1.09046 \mathrm{E}-01$ & $-2.45525 \mathrm{E}-01$ & $4.44276 \mathrm{E}+00$ \\
\hline Ortho substitution & $-3.65254 \mathrm{E}-03$ & $2.57744 \mathrm{E}-02$ & $-4.08265 \mathrm{E}+00$ \\
\hline Meta substitution & $6.98374 \mathrm{E}-03$ & $4.87704 \mathrm{E}-02$ & $-3.86336 \mathrm{E}+00$ \\
\hline Para substitution & $1.10481 \mathrm{E}-02$ & $5.96276 \mathrm{E}-02$ & $-3.70672 \mathrm{E}+00$ \\
\hline Substitution in positions 1-2-3 & $2.28164 \mathrm{E}-02$ & $6.55366 \mathrm{E}-02$ & $-2.56483 \mathrm{E}+00$ \\
\hline Substitution in positions 1-2-4 & $4.09258 \mathrm{E}-02$ & $1.14323 \mathrm{E}-01$ & $-2.62311 \mathrm{E}+00$ \\
\hline Substitution in positions 1-3-5 & $6.20632 \mathrm{E}-02$ & $1.30913 \mathrm{E}-01$ & $-2.56483 \mathrm{E}+00$ \\
\hline Substitution in positions 1-2-6 & $3.68598 \mathrm{E}-02$ & $1.26470 \mathrm{E}-01$ & $-2.73968 \mathrm{E}+00$ \\
\hline Substitution in positions 1-3-4 & $3.67809 \mathrm{E}-02$ & $1.26470 \mathrm{E}-01$ & $-2.73968 \mathrm{E}+00$ \\
\hline Substitution in positions 1-2-4-5 & $7.41083 \mathrm{E}-02$ & $1.43832 \mathrm{E}-01$ & $-1.71712 \mathrm{E}+00$ \\
\hline Substitution in positions 1-2-3-4 & $5.30596 \mathrm{E}-02$ & $1.76744 \mathrm{E}-01$ & $-1.71712 \mathrm{E}+00$ \\
\hline Substitution in positions 1-2-3-5 & $5.70868 \mathrm{E}-02$ & $1.76744 \mathrm{E}-01$ & $-1.71712 \mathrm{E}+00$ \\
\hline & & & \\
\hline
\end{tabular}

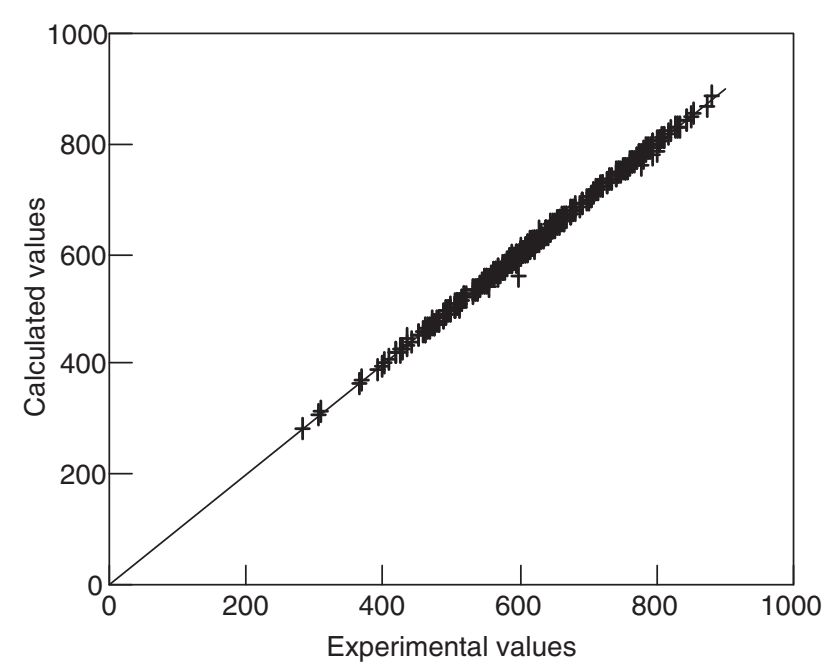

Figure 1

Calculated $v s$ experimental critical temperatures.

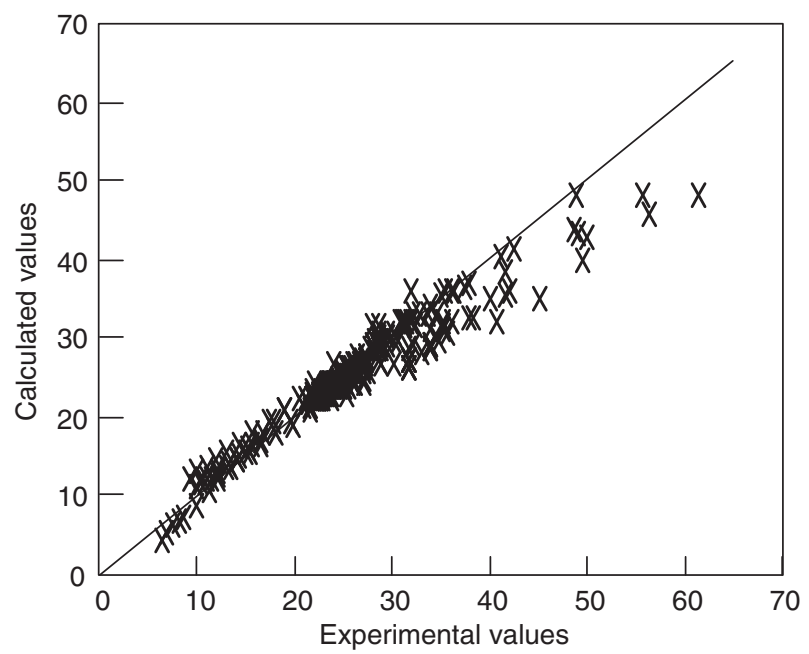

Figure 2

Calculated vs experimental critical pressures.

This model gives an absolute average deviation of $1.7 \%$ relatively to reference data.

The group contributions and equation parameters are given in Table 5 .

The comparison between experimental and calculated properties in our approach is shown in Figures 1,2 and 3 for critical temperature, critical pressure and critical volume respectively.

The illustrative use of the proposed method is shown in Appendix. 


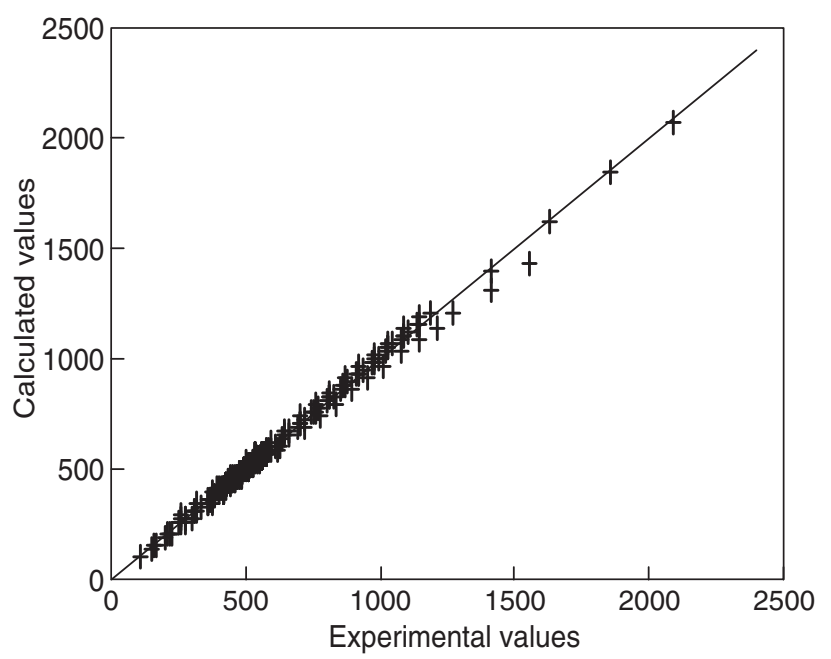

Figure 3

Calculated vs experimental critical volumes.

\section{COMPARISON WITH OTHER METHODS}

To test the accuracy of the proposed equations, we have compared their average absolute deviations to those registered by other methods such as Joback (1984), Constantinou and Gani (1994, 1995) and Marrero and Gani (2001) methods. The results obtained and given in Table 6 show that our approach gives significantly more accurate predictions than the methods given in literature, particularly for isoparaffins.

\section{CONCLUSION}

A group-contribution method was developed and has been successfully applied to the estimation of the critical properties for pure hydrocarbons. In this work, a total of 375 pure hydrocarbons have been examined by using the 40 predictive group contributions. Comparison with experimental data gave absolute average deviations of $0.36 \%, 4.6 \%$ and $1.7 \%$ for critical temperature, critical pressure and critical volume respectively. The proposed method is more accurate than Joback's, Constantinou's and Marrero's, particularly in the case of isoparaffins.

Besides, the proposed equations remain valid in the case of long chain paraffins (up to $\mathrm{C}_{40}$ ), which is not the case of the majority of other group contribution methods.

An extension of the present work will consist of the application of the proposed correlations to the prediction of mixtures and petroleum fraction properties.

\section{REFERENCES}

Ambrose, D. (1980) National Physical Laboratory, Teddington, NPL Rep. Chem., 107.

Constantinou, L., Gani, R. (1994) AICHE J., 40, 1697-1710.

TABLE 6

Comparison of the accuracy between existing correlations and the proposed equations

\begin{tabular}{|c|c|c|c|c|c|c|}
\hline & n-paraffins & i-paraffins & Alkenes & alkynes & naphthenes & aromatics \\
\hline \multicolumn{7}{|l|}{ Critical temperature } \\
\hline Proposed correlation & 0.2 & 0.3 & 0.3 & 0.8 & 0.4 & 0.4 \\
\hline Joback (1984) & 2.3 & 0.5 & 0.6 & 2.2 & 0.5 & 0.4 \\
\hline Constantinou and Gani (1994) & 2.1 & 1.7 & 1.7 & 3.2 & 1.6 & 1.1 \\
\hline Marrero and Gani (2001) & 1.2 & 1.6 & 1.3 & 1.1 & 2.3 & 1.0 \\
\hline \multicolumn{7}{|l|}{ Critical pressure } \\
\hline Proposed correlation & 7.3 & 0.5 & 3.8 & 7.2 & 11.3 & 6.5 \\
\hline Joback (1984) & 7.8 & 5.6 & 3.6 & 5.0 & 5.9 & 9.2 \\
\hline Constantinou and Gani (1994) & 6.9 & 4.8 & 5.2 & 4.9 & 7.2 & 5.0 \\
\hline Marrero and Gani (2001) & 11.3 & 4.0 & 5.7 & 7.3 & 12.3 & 5.4 \\
\hline \multicolumn{7}{|l|}{ Critical volume } \\
\hline Proposed correlation & 1.6 & 0.9 & 1.7 & 2.6 & 1.8 & 3.0 \\
\hline Joback (1984) & 1.4 & 2.8 & 1.7 & 1.1 & 0.8 & 2.8 \\
\hline Constantinou and Gani (1994) & 1.3 & 1.9 & 2.3 & 1.5 & 3.6 & 4.0 \\
\hline Marrero and Gani (2001) & 1.3 & 1.8 & 2.7 & 1.8 & 3.7 & 2.3 \\
\hline
\end{tabular}


Constantinou, L., Gani, R., O’Connell, J.P. (1995) Fluid Phase Equilibr., 103, 11-22.

DIPPR Data Compilation of Pure Compound Properties (1985) version 9.2

Joback, K.G. (1984) S. M. thesis in Chemical Engineering, Massachuset Institute of Technology, Cambridge, Mass.

Klincewicz, K.M., Reid, R.C. (1984) AICHE J., 30, 137.

Lydersen, A.L. (1955) Coll. Eng. Univ. Wisconsin, Engineering Experimental Station Rept. 3.
Marrero, J., Gani., R. (2001) Fluid Phase Equilibr., 183-184, 183-208.

Reid, R.C., Prausnitz, J.M., Poling, B.E. (1987), The properties of gases and liquids, 4th edn., McGraw- Hill, New York.

TRC Tables (1994) Thermodynamic Data Base, version 1.3.

Final manuscript received in October 2006 


\section{APPENDIX}

To illustrate the proposed method, we provide the estimation of the critical properties of 2.2.3-trimethylheptan, deylcyclohexan and 2-ethyl-p-xylene.

\subsection{3-trimethylheptan}

\begin{tabular}{c|c|c|c}
\hline Groups & $\boldsymbol{T}_{\boldsymbol{C}}$ & $\boldsymbol{P}_{\boldsymbol{C}}$ & $\boldsymbol{V}_{\boldsymbol{C}}$ \\
\hline$-\mathrm{CH}_{3}$ & $5 \times 1.99670 \mathrm{E}-01$ & $5 \times 1.98848 \mathrm{E}-05$ & $5 \times 1.31664 \mathrm{E}+01$ \\
\hline$-\mathrm{CH}_{2}-$ & $3 \times 9.15532 \mathrm{E}-02$ & $3 \times 1.12008 \mathrm{E}-01$ & $3 \times 1.06879 \mathrm{E}+01$ \\
\hline$>\mathrm{CH}-$ & $1 \times(-6.11156 \mathrm{E}-02)$ & $1 \times 2.01649 \mathrm{E}-01$ & $1 \times 5.15453 \mathrm{E}+00$ \\
\hline$>\mathrm{C}<$ & $1 \times(-2.48688 \mathrm{E}-01)$ & $1 \times 2.45728 \mathrm{E}-01$ & $1 \times(-9.39285 \mathrm{E}-01)$ \\
\hline Correction terms & & & $1 \times 3.73376 \mathrm{E}-02$ \\
\hline $\mathrm{C}\left(\mathrm{CH}_{3}\right)_{3}$ & $1 \times 3.53048 \mathrm{E}-02$ & $2 \times(-1.62746 \mathrm{E}-02)$ & $2 \times(-1.02605 \mathrm{E}-01)$ \\
\hline $\mathrm{C}\left(\mathrm{CH}_{3}\right)$ & $2 \times(-6.78177 \mathrm{E}-03)$ & $1 \times(-1.15443 \mathrm{E}-02)$ & $1 \times(-4.72746 \mathrm{E}-01)$ \\
\hline $\mathrm{C}\left(\mathrm{CH}_{3}\right) 1 \mathrm{C}(\mathrm{CH})_{3}$ & $1 \times(-1.37746 \mathrm{E}-02)$ & $23.1 \mathrm{bar}$ & $564.0 \mathrm{~cm} / \mathrm{mol}^{3}$ \\
\hline Calculated value & $611.6 \mathrm{~K}$ & $23.0 \mathrm{bar}$ & $562.1 \mathrm{~cm} / \mathrm{mol}^{3}$ \\
\hline Experimental value & $610.6 \mathrm{~K}$ & 0.4 & 0.3 \\
\hline Absolute deviation $(\%)$ & 0.2 & & \\
\hline
\end{tabular}

\section{Decylcyclohexan}

\begin{tabular}{c|c|c|c}
\hline Groups & $\boldsymbol{T}_{\boldsymbol{C}}$ & $\boldsymbol{P}_{\boldsymbol{C}}$ & $\boldsymbol{V}_{\boldsymbol{C}}$ \\
\hline$-\mathrm{CH}_{3}$ & $1 \times 1.99670 \mathrm{E}-01$ & $1 \times 1.98848 \mathrm{E}-05$ & $1 \times 1.31664 \mathrm{E}+01$ \\
\hline$-\mathrm{CH}_{2}-$ & $14 \times 9.15532 \mathrm{E}-02$ & $14 \times 1.12008 \mathrm{E}-01$ & $14 \times 1.06879 \mathrm{E}+01$ \\
\hline$>\mathrm{CH}-$ & $1 \times(-6.11156 \mathrm{E}-02)$ & $1 \times 2.01649 \mathrm{E}-01$ & $1 \times 5.15453 \mathrm{E}+00$ \\
\hline Correction terms & & & $1 \times(-4.96039 \mathrm{E}+00)$ \\
\hline 6 membered ring & $1 \times 7.88993 \mathrm{E}-02$ & $14.8 \mathrm{bar}$ & $867.1 \mathrm{~cm}^{3} / \mathrm{mol}$ \\
\hline Calculated value & $750.3 \mathrm{~K}$ & $14.0 \mathrm{bar}$ & $857.0 \mathrm{~cm}^{3} / \mathrm{mol}$ \\
\hline Experimental value & $747.7 \mathrm{~K}$ & 5.7 & 1.2 \\
\hline Absolute deviation (\%) & 0.3 & & \\
\hline
\end{tabular}

\section{2-ethyl-p-xylene}

\begin{tabular}{c|c|c|c}
\hline Groups & $\boldsymbol{T}_{\boldsymbol{C}}$ & $\boldsymbol{P}_{\boldsymbol{C}}$ & $\boldsymbol{V}_{\boldsymbol{C}}$ \\
\hline -CH3 & $3 \times 1.99670 \mathrm{E}-01$ & $3 \times 1.98848 \mathrm{E}-05$ & $3 \times 1.31664 \mathrm{E}+01$ \\
\hline$-\mathrm{CH} 2-$ & $1 \times 9.15532 \mathrm{E}-02$ & $1 \times 1.12008 \mathrm{E}-01$ & $1 \times 1.06879 \mathrm{E}+01$ \\
\hline$=\mathrm{CH}-$ & $3 \times 7.10096 \mathrm{E}-2$ & $3 \times 5.37104 \mathrm{E}-2$ & $3 \times 8.20223 \mathrm{E} 00$ \\
\hline$=\mathrm{C}<$ & $3 \times(-5.34718 \mathrm{E}-2)$ & $3 \times 1.15424 \mathrm{E}-1$ & $3 \times 4.70117 \mathrm{E} 00$ \\
\hline Correction terms & & & $4.44276 \mathrm{E}+00$ \\
\hline Aromatic ring & $1.09046 \mathrm{E}-01$ & $1.14323 \mathrm{E}-01$ & $-2.62311 \mathrm{E}+00$ \\
\hline Substitution in position 1.2 .4 & $4.09258 \mathrm{E}-02$ & $28.9 \mathrm{bar}$ & $482.6 \mathrm{~cm} 3 / \mathrm{mol}$ \\
\hline Calculated value & $662.9 \mathrm{~K}$ & $28.6 \mathrm{bar}$ & $482.0 \mathrm{~cm} 3 / \mathrm{mol}^{2}$ \\
\hline Experimental value & $663.4 \mathrm{~K}$ & 1.1 & 0.12 \\
\hline Absolute deviation $(\%)$ & 0.08 & & \\
\hline
\end{tabular}

